\title{
AZ ISKOLAI SZELEKCIÓ HATÁSÁNAK ELEMZÉSE A KÉPESSÉGEK FEJLŐDÉSÉNEK SZÁMÍTÓGÉPES SZIMULÁCIÓJA SEGÍTSÉGÉVEL*
}

\author{
CSAPÓ BENŐ \\ Szegedi Tudományegyetem, Neveléstudományi Tanszék, Szeged \\ E-mail: csapo@edpsy.u-szeged.hu
}

\begin{abstract}
A tanulmány egy szimulációs modell segítségével azt elemzi, hogy a képességek korai fejlettségi szintjéböl milyen biztonsággal lehet a később elért szintre következtetni, és megvizsgálja, hogy az eredményeknek milyen konzekvenciái vannak az iskolai szelekciós mechanizmusokra. Az elemzés empirikus alapjául az induktív gondolkodással négy életkorban (az 5., 7., 9. és 11. évfolyamokon) összesen közel 7800 tanulóval elvégzett felmérés szolgált. Az elsó lépesben a mérési adatokhoz (a megfelelö életkori csoportok átlagához) egy logisztikus görbét illesztettünk, meghatároztuk a görbe paramétereit. Ezután a hetedik évfolyam adataiból kiindulva minden egyes egyénhez egy logisztikus görbét generáltunk úgy, hogy az eleget tegyen a következö feltételeknek: a szimulált adatok átlaga feleljen meg a felmérésböl származó tapasztalati adatoknak, és az egyes életkorok közötti korrelációk feleljenek meg az irodalomból ismert tipikus értékeknek. Az igy elóállított adatbázis segítségével megvizsgáltuk, milyen eséllyel maradnak az adott fejlettségi sávban azok a tanulók, akiket a 4., a 6. vagy a 8. évfolyamon az akkori fejlettségük alapján mint legfejlettebbeket kiválasztottunk. Az elemzéshez a 8, a 6 és a 4 osztályos gimnáziumok valódi beiskolázási arányait használtuk fel. Elemzéseink azt mutatták, hogy ha a fejlödés a modellben feltételezett szabályok szerint menne végbe, akkor a 10 éves korban kiválasztott felsö 3,5\%-nak csak egyötöde, a 12 évesek közül kiválasztott 9,6\%-nak több mint a fele, a 14 évesek közül kiválasztott felsó 31,6\%-nak pedig a négyötöde marad az adott felsô sávban a 12 évfolyam végére. A szimulált adatbázis segítségével tetszőleges más arányok mellett is el lehet végezni a modellszámításokat. Az eredmények értékelésénél figyelembe kell venni, hogy a gyakorlatban a kognitív fejlödés folyamatait számos személyes tulajdonság és a szocio-kulturális hatások is befolyásolják.
\end{abstract}

Kulcsszavak: $\quad$ szimuláció, modell, képességek stabilitása, képességek fejlödése, induktív gondolkodás, iskolai szelekció

* A tanulmány korábbi változata „A hat- és nyolcosztályos gimnáziumok a magyar oktatási rendszerben” című kutatási programhoz készült. Az elemzésekhez a SZTE-MTA Képességkutató Csoport keretében az OTKA T030555 és az OM támogatásával végzett vizsgálatok adatait használtuk fel. 
A pedagógiai és pszichológiai kutatás az elmúlt évszázad során óriási tömegű adatot halmozott fel az értelmi fejlödéssel kapcsolatban. Ugyanakkor bizonyos típusú vizsgálatokat, amelyek pedig gyakorlati szempontból fontos információkat szolgáltatnának, rendkívül költséges elvégezni vagy akkora szervező-koordináló munkát igényelnek, hogy azokra csak ritkán kerül sor. Egy olyan bonyolult rendszer esetében, mint amilyen a közoktatás, az is gyakran előfordul, hogy részinformációk sokasága áll rendelkezésünkre, de ezek nem írják le kielégítően azokat a folyamatokat, amelyek megértése pedig szükséges lenne bizonyos döntések meghozatalához. Ilyen esetekben lehet segítségünkre a modellezés és a szimuláció: a részeredményeket egy nagyobb egésszé rakjuk össze, a hiányzó elemeket megalapozott feltevéseken nyugvó számítások eredményivel egészítjük ki.

A tudományos kutatatás módszertanában elég pontosan körülhatárolható a »modellezés« és a »szimuláció» terminusok értelmezése. E kifejezések pontos meghatározása és megkülönböztetése meghaladná e tanulmány kereteit, mindamellett érdemes rögzíteni, hogy a következőkben milyen értelemben használjuk e terminusokat. Modellen a képességek fejlődéséről, közelebbről a fejlődés mennyiségi természetéről alkotott matematikai leírást értjük. Egy korábbi tanulmány bemutatja, hogy a képességek fejlődése jó közelítéssel leírható a logisztikus függvénnyel, a mért adatok nagy pontossággal illeszkednek a logisztikus görbére (MOLNÁR, CSAPÓ, megjelenés alatt). Ezt a leírást - mindazokkal a feltevésekkel együtt, amelyek a növekedés logisztikus természetét értelmezik - a fejlődés matematikai modelljének tekinthetjük. A szimuláció egy bonyolult rendszer viselkedésének tanulmányozására alkalmas kutatási technika. A rendelkezésre álló adatok alapján létrehozunk egy elgondolt rendszert vagy egy valós rendszernek valamilyen elképzelhető, de a valóságban közvetlenül nem megfigyelhető állapotát, viselkedését (OHLSSON, 1988). Ilyen szimulációs technikával vizsgálta például NAGY József (1974) azt, hogyan működne a kompenzáló beiskolázás.

A képességek fejlődéséről alkotott logisztikus modellt itt további összefüggések figyelembevételével bővítjük ki, és számítógépes szimulációval létrehozunk egy olyan adatbázist, amely a valódi felmérések adataiból indul ki, és a szimulált adatok összhangban vannak a valódi, mért adatok összes ismert paraméterével.

A nehezen elvégezhető, éppen ezért ritka vizsgálatokra típuspéldaként szolgálhat a fejlődés longitudinális elemzése, azaz egy kiválasztott minta nyomon követése és folyamatos vagy legalábbis rendszeres felmérése. Longitudinális adatok nélkül pedig nem lehet olyan kérdéseket megválaszolni, mint például, hogy mennyire stabilak a fejlődés kisiskolás korban megfigyelhető tendenciái. Vannak azonban olyan longitudinális adatok, amelyek bár más jellegű felmérések során keletkeztek, számunkra is hasznosak lehetnek. Ezeket az adatokat felhasználhatjuk olyan adatbázisok generálásához, amelyek már pedagógiai problémák elemzésére is alkalmasak. 


\section{A KÉPESSÉGEK FEJLŐDÉSÉNEK STABILITÁSA}

Már az intelligenciakutatás korai szakaszában felmerült az a kérdés, vajon hosszú távon stabilak-e a kognitív képességek, és ha igen, milyen mértékben? Lényegében arról van szó, hogy a fejlődés valamely korai szakaszában elért szintből milyen biztonsággal lehet előre jelezni egy későbbi szintet. Másként fogalmazva, a fiatal korban átlag alatti vagy átlag feletti intellektuális képességek milyen mértékben előjelei a később elért teljesítményeknek? Mekkora a valószínűsége annak, hogy ha valaki gyermekkorban kiemelkedő képességeket mutat, felnőttként is átlagon felüli eredményeket ér el? A probléma a nevezetes IQ-vita egyik szálaként is a figyelem középpontjába került, és mind a kérdés elméleti vonatkozásait, mind pedig tágabb társadalmi összefüggéseit sokoldalúan elemezték az elmúlt három évtizedben. (Az eredeti vita kontextusában lásd JENSEN, 1969; a képességek szintjének stabilitását illetően: CARROLL, 1993, 662-674; ANDERSON, 1998, 15-20.)

A kérdés nem új az oktatás világában sem (tulajdonképpen az IQ-vita is pedagógiai kérdések nyomán robban ki), és többek között a tehetségek korai felismerésével, kiválasztásával, a tehetséggondozással kapcsolatban óriási irodalma van. Ugyanez az alapjában véve fejlődéspszichológiai kérdés áll az iskolai szelekcióval, az iskolafokozatok egymásra épülésével, az elágazással és egységességgel kapcsolatos dilemmák hátterében is, amit gyakran tovább árnyalnak - vagy néha teljesen elfednek - a társadalmi, oktatáspolitikai vagy általánosabb politikai szempontok.

A kérdés megválaszolásához longitudinális felméréseket kellene végezni, olyan feltételek között, amikor hosszú időszakon keresztül garantálni lehetne a fejlődés feltételeinek állandóságát. Ezek a vizsgálatok rendkívül költségesek és hosszú ideig tartanak, gyakorlatilag annyi ideig, ahány éves fejlődési periódust az elemzés átfog. Ennek ellenére vannak ilyen longitudinális adatok. Elsősorban az intelligencia, illetve az értelmi képességek kutatásának keretében számos olyan vizsgálatot végeztek, amely a gyerekek fejlődését éveken át követte, így lehetőség nyílt a stabilitás elemzésére, a különböző életkorban mért teljesítményeik közötti korrelációk kiszámítására. Érdemes ezek közül néhány eredményét felidéznünk annak illusztrálására, milyen nagyságúak a tipikus korrelációk, a későbbiekben, a szimuláció során ugyanis olyan adatbázist szándékozunk előállítani, amely a különböző életkorok közötti korrelációk tekintetében is jól megközelíti a tapasztalati adatokat.

HÄRNQVIST (1968) a g-faktor stabilitását vizsgálta a gyerekek 13 és 18 éves korban felvett adatainak összehasonlításával. A két mérési pontban nyújtott teljesítmények között - amelyek tehát ötévnyi távolságra voltak egymástól - a korrelációs együttható 0,78-nak adódott (idézi CAROLL, 1993, 669).

A seattle-i longitudinális felmérés hét éven át tartott, és több intellektuális képességre kiterjedt (SCHAIE, STROTHER, 1968). Az eredményeket az 1. táblázatban foglaltuk össze. A különböző életkorokban mért teljesítmények közötti korrelációk e vizsgálatban tipikusan 0,75 és 0,93 között változnak (idézi CARROLL, 1993, 663). 
1. táblázat. A hét év különbséggel felmért kognitív képességek közötti korreláció (SCHAiE és STROTHeR, 1968 alapján)

\begin{tabular}{|l|c|}
\hline \multicolumn{1}{|c|}{ Képesség } & Korreláció a két felmérés adatai között \\
\hline Verbális jelentés & 0,88 \\
\hline Térbeli gondolkodás & 0,75 \\
\hline Érvelés & 0,93 \\
\hline Számolási készség & 0,91 \\
\hline Beszéd-fluencia & 0,86 \\
\hline
\end{tabular}

Hindley és Owen egy longitudinális vizsgálat során háromévenkénti rendszerességgel végezett felméréseket. Itt a különböző életkorok eredményei között már több korrelációit is ki lehet számítani (2. táblázat). Ahogy az várható, az összefüggések a legközelebbi életkorok között a legszorosabbak, és a két legtávolabbi időpont, az 5 és 17 éves korban mért IQ-k közötti korreláció kb. 0,6 nagyságú (ismerteti ANDERSON, 1998).

2. táblázat. A különböző életkorban mért intelligencia közötti korreláció (HINDLEY, OWEN, 1978)

\begin{tabular}{|c|c|c|c|c|}
\hline Kor & 5 éves & 8 éves & 11 éves & 14 éves \\
\hline 8 éves & 0,76 & \multicolumn{3}{|l}{} \\
\hline 11 éves & 0,78 & 0,88 & 0,70 & \\
\hline 14 éves & 0,57 & 0,70 & 0,68 & 0,86 \\
\hline 17 éves & 0,62 & 0,76 & 0 \\
\hline
\end{tabular}

A korrelációs együttható négyzete, az ún. determinációs együttható mutatja meg, hogy az egyik változó segítségével a másik változó varianciájának milyen aránya értelmezhető. Ezt figyelembe véve azt mondhatjuk, hogy a kisgyermekkorban felvett tesztekkel a felnőtt intelligencia körülbelül 40-50 százalékban jelezhető előre. JENSEN (1969, 36-37) ugyancsak a 0,7 körüli korrelációt tartja átlagosnak a kisgyermekkori és a fiatal felnőttkori értelmi képességek között, ami azt jelenti, hogy felnőttkori variancia nagyjából 50\%-a magyarázható a kisgyermekkori fejlettség alapján. Érdemes itt emlékeztetni arra, hogy Jensen az örökléselvűek nézeteit képviselte, és pesszimistán tekintett az oktatás lehetőségeire. Ugyanakkor mint később látni fogjuk - még a legkonzervatívabb adatokból kiindulva, a tapasztalatinál kissé szorosabb korrelációkkal számolva sem olyan korlátok közé szorítottak és előre láthatóak a tanulók képességének fejlődési pályái, mint ahogyan azt gyakran hajlamosak vagyunk feltételezni.

Ezek az adatok ugyanis azt mutatják, hogy bár viszonylag szoros korreláció van ugyanannak a személynek a különböző időpontokban felmért teljesítményei kö- 
zött, a képességek fejlődése korántsem abban az értelemben meghatározott, ahogy azt a hétköznapi szemléletünk sugallja. Ha ugyanis a gyerekek az évek múltával egy-egy képesség fejlődése tekintetében megőriznék egymáshoz viszonyított helyzetüket, azt a sorrendet, amelyet egy korábbi időpontban megfigyeltünk, akkor a korreláció értéke 1 körül lenne. Az 1-nél kisebb korrelációs együtthatók azt jelzik, hogy a gyerekek relatív helyzete a fejlődés során változik, egyesek megelőznek másokat.

A szimuláció segítségével ezt a jelenséget tanulmányozzuk részletesebben. Az ismert kutatási eredmények alapján megvizsgáljuk, hogy milyen szerepet játszik a tanulók képességeinek stabilitása, illetve változékonysága az iskolázás szempontjából releváns életkori szakaszban. Mielőtt azonban a számításokra rátérnénk, érdemes áttekinteni az iskolázás és a képességfejlődés kapcsolatát, közelebbről azt, hogyan befolyásolja, módosítja az iskolarendszer, vagyis annak szelekciós mechanizmusa a képességek fejlődési folyamatait.

\section{AZ ISKOLARENDSZER HATÁSA A FEJLŐDÉSRE}

A tanulók fejlődése természetesen nem minden tekintetben „előre programozott”, azaz a környezeti feltételek, mindenekelőtt az iskolai oktatás alakítja fejlődésüket. A magyarországi empirikus kutatások alapján áttekinthetjük, milyen jellegủek ezek a hatások. Itt most csak a szegedi vizsgálatok néhány fontosabb eredményét idézzük fel.

A számolási és szövegesfeladat-megoldási készségeket Nagy József az 1960-as évek végétől országos reprezentatív mintákon vizsgálta, az említett alapkészségek fejlődését az iskolába lépéstől egészen az érettségiig tartó életszakaszban feltérképezte. Így erre a két készségcsoportra vonatkozóan hosszú távú adatokkal rendelkezünk. Az elemi számolási készségek fejlődése az általános iskola után iskolatípusok szerint polarizálódik. Az adatok azt mutatják, hogy az elsős gimnazisták általános iskola utáni fejlődésbeli megugrása tapasztalható, ami annak következménye, hogy középiskolába az aktuálisan fejlettebb tanulók kerülnek be. A szakmunkástanulók számolási készségének fejlődése viszont erősen lelassul (NAGY, 1971).

Ugyanez a tendencia figyelhető meg a szövegesfeladat-megoldással kapcsolatos felmérés eredményeiben is. A három iskolatípus közül legjobban a gimnazisták teljesítenek (94,0\%), kicsit lemaradva tőlük következnek a szakközépiskolások $(90,5 \%)$, majd végül messze leszakadva utolsóként a szakmunkásképzők tanulói $(81,5 \%)$. A tizedik évfolyamra járó szakmunkástanulók eredménye alacsonyabb a nyolcadikosok átlagánál. A tizedik osztályos szakmunkástanulók fejlődésben több mint két évvel maradnak el kortársaiktól (VIDÁKOVICH, CSAPÓ, 1998).

Hasonló elkülönülést mutatnak az induktív gondolkodást vizsgáló tesztek eredményei is. A különböző iskolatípusokba járó gyerekek között jelentős különbség van, és a fejlődés tempója eltérő az egyes iskolatípusokban. Az adatok arra engednek következtetni, hogy a felnövekvő populáció tagjait nemcsak a természetes életkori polarizáció távolítja el egymástól, hanem az iskolai elkülönítés is szerepet játszik az egyének közötti különbségek kialakulásában és növekedésében. 
Az induktív gondolkodás fejlettségét a hetedik évfolyamon felmérve közel normális eloszlású görbét kapunk. Ha viszont a tizenegyedik évfolyam adatait együtt tekintjük, ezek már bimodális eloszlást mutatnak, ami a teljesítmények szétválására, polarizációjára utal. Ha a két iskolatípusba (gimnázium, szakközépiskola) járó tanulók adatait szétválasztjuk, és eloszlásukat külön ábrázoljuk, az eloszlás bimodális jellege megszűnik, két különböző helyzetű, de csaknem normális eloszlást kapunk. Mindez a két iskolatípusba beiskolázott tanulók közötti különbségek olyan mértékủ megnövekedését jelzi, hogy a teljesítmények együttes eloszlása már különböző paraméterekkel rendelkező populáció jelenlétére utal (CSAPÓ, 1998).

A képességek fejlődésével kapcsolatos felmérésekből kitűnik, hogy az iskolarendszer jellegzetességei, magának az iskolai oktatásnak a fejlesztő hatásai, az iskolafokozatok és iskolatípusok közötti különbségek sokféle módon befolyásolják a fejlődést. Így a szimuláció lehetőséget ad arra is, hogy megnézzük, miként alakulnának a képességek, ha a fejlódés a maga „tiszta” formájában, a matematikai törvényszerűségeket követve mehetne végbe.

\section{A SZIMULÁLT ADATBÁZIS ELKÉSZÍTÉSE}

A szimulációs számításokhoz az induktív gondolkodás 1999 áprilisában végzett országos felmérésének adatait használjuk. Kiindulásként kiszámítottuk az adatokhoz legjobban illeszkedő logisztikus görbe paramétereit. A görbe egyenletét a

$$
\mathrm{F}(\mathrm{t})=\left\{\mathrm{K} \cdot \mathrm{F}_{0} \cdot \mathrm{e}^{\mathrm{rt}} /\left[\mathrm{F}_{0} \cdot\left(\mathrm{e}^{\mathrm{rt}}-1\right)+\mathrm{K}\right]\right\}+\mathrm{a}
$$

formában adhatjuk meg, ahol $F(t)$ a fejlettség $t$ idő elteltével; $F_{0}$ a kezdeti fejlettség (a $t=0$ időpontban); $K$ a fejlődés korlátja; $r$ a növekedést meghatározó konstans, a növekedési ráta. Az induktív gondolkodás fejlődését leíró görbe konkrét paraméterei: $r=0,531, F_{0}=0,037, K=42, a=20$. (Bővebben lásd CSAPÓ, megjelenés alatt.)

A mért adatokat és az illesztett görbét az 1.ábrán mutatjuk be. A felmérés eredményeként kapott adatok pontos értékei (az átlagok és a szórások) megtalálhatók a 3. táblázatban.

3. táblázat. Az induktív gondolkodás felmérésének eredményei (országos adatok, 1999)

\begin{tabular}{|c|c|c|c|}
\hline Évfolyam & $\mathrm{N}$ & Átlag & Szórás \\
\hline 5. & 2077 & 28,9 & 14,9 \\
\hline 7. & 2015 & 40,8 & 16,8 \\
\hline 9. & 1915 & 49,1 & 18,1 \\
\hline 11. & 1765 & 57,2 & 17,5 \\
\hline
\end{tabular}




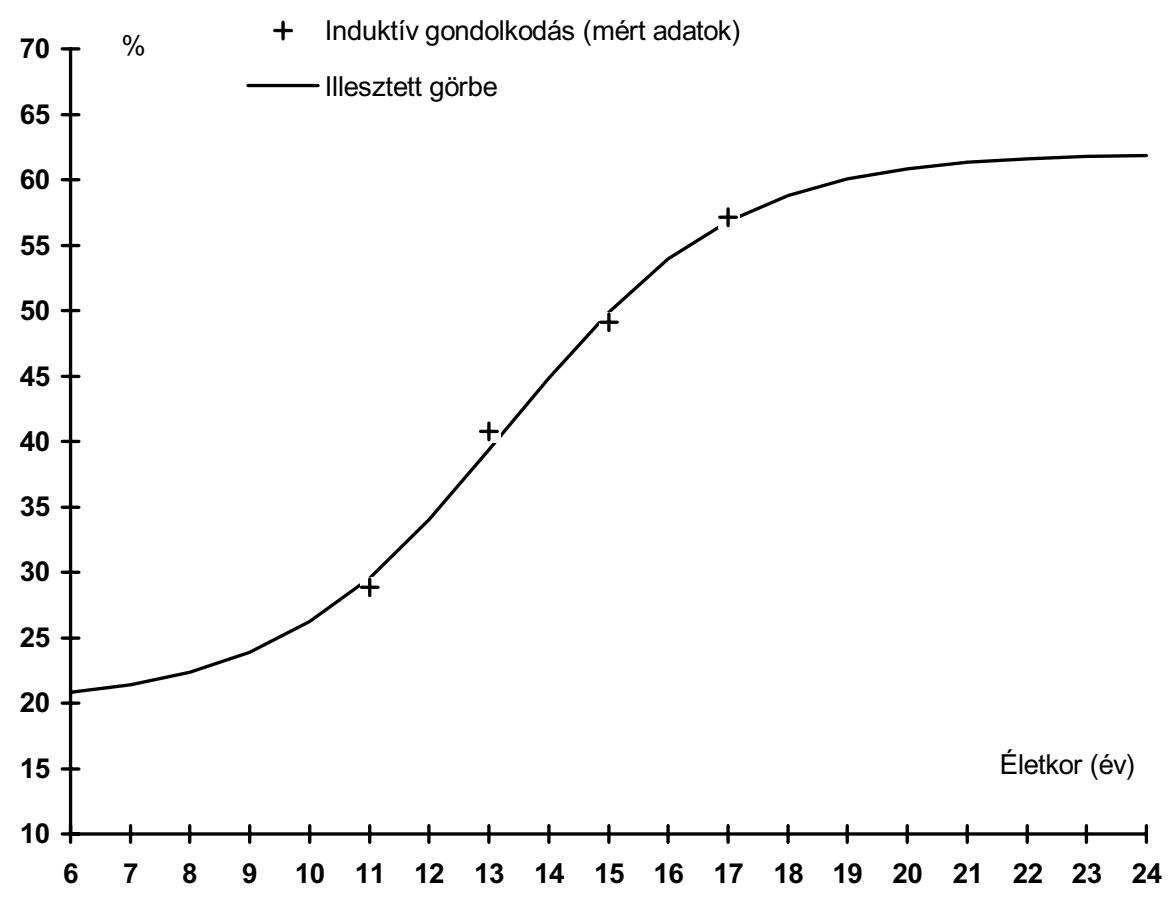

1. ábra. Az induktív gondolkodás országos reprezentatív felmérésének adataira illesztett logisztikus görbe

A következő lépésben a korábban bemutatott alapelvek szerint, a meglevő kutatási eredményeket felhasználva elkészítettünk egy olyan adatbázist, amely megfelel vizsgálataink adatainak és a képességek egyéb ismert sajátosságainak. A szimulációt a következő alapelvek szerint az alábbi kiinduló feltételekkel végeztük.

1. Kiinduló adatbázisként az 1999-ben elvégzett országos reprezentatív vizsgálatból az induktív gondolkodás adatait használjuk fel. Az induktív gondolkodás fejlődése széles életkori sávot fog át, jól jellemzi az általános értelmi képességeket, így különösen alkalmas arra, hogy segítségével az értelmi fejlődés sajátosságait tanulmányozzuk. Mivel az induktív gondolkodás nagyon szoros kapcsolatban áll sok más kognitív képességgel, többek között a tanulási potenciállal is, segítségével az iskolai szelekció hatásai is elemezhetőek. A felmérés négy életkorra terjedt ki, a pontos áltagokat és a szórásokat a 3. táblázat tartalmazza.

2. Feltételeztük, hogy a populációban minden egyes tanuló fejlődése a logisztikus görbe szerint megy végbe.

3. A hetedik évfolyam adatait felhasználva létrehoztunk egy adatbázist úgy, hogy minden egyes felmért tanuló adatához a logisztikus összefüggést felhasználva kiszámítottuk a többi életkor adatait. Tehát minden egyes tanulóhoz tartozik egy logisztikus görbe. 
4. A tanulók görbéinek paramétereit úgy határoztuk meg, hogy a hetedikes adatok alapján kiszámítottunk egy korlátot $(K)$ és egy kezdeti értéket $(a)$. Az egyes tanulók paramétereinek különbségeit úgy hoztuk létre, hogy azokat az átlagtól véletlenszám-generátorral eltérítettük. A véletlen számok (egyenletes és normális eloszlású) használata arra szolgál, hogy a tanulókat minden felhasznált paraméter tekintetében „egyénivé”, egymástól különbözővé tegyük.

5. A véletlen számok arányát úgy állítottuk be, hogy a különböző életkorok között számított összefüggések megfeleljenek azoknak az adatoknak, amit a szakirodalomban találtunk. Mivel itt nagyon sokféle módon meg lehet közelíteni a valós helyzetet, realisztikus, tapasztalati adatok megadásával és számos próbálkozással, az arányok fokozatos finomításával jutottunk el a valóságot jól megközelítő szimulált adatokhoz.

4. táblázat. Az induktív gondolkodás szimulált adatai

\begin{tabular}{|c|c|c|c|}
\hline Évfolyam & $\mathrm{N}$ & Átlag & Szórás \\
\hline 5. & 2006 & 31,1 & 12,8 \\
\hline 7. & 2006 & 40,4 & 16,5 \\
\hline 9. & 2006 & 50,8 & 22,0 \\
\hline 11. & 2006 & 58,8 & 16,5 \\
\hline
\end{tabular}

Az előzőekben leírt módon kiszámítottuk az adatbázishoz szükséges adatokat, az előállított adatokat a 4. táblázatban mutatjuk be. Amint a 3. és a 4. táblázat összehasonlításából kitűnik, a számított adatok jó közelítéssel, csaknem egy százalékos pontossággal megegyeznek a mért adatokkal. A szórások is jó egyezést mutatnak. Természetesen a teljes egyezésre nem számíthatunk, hiszen itt rendkívül bonyolult, sok egyedi tényező által meghatározott összefüggésrendszerről van szó. Magában az eljárásban is számos pontatlanságot előidéző tényező van. A tesztek korlátozott pontosságán és az adatfelvétel bizonytalanságain túl az is rontja az elemzés pontosságát, hogy az életkor jellemzésére kerek évszámokat használtunk. Mindezeket figyelembe véve az egyezés egészen jónak tekinthető.

A szimuláció egyik legfontosabb kritériuma az volt, hogy így az előállított, longitudinális felmérésnek megfelelő adatok között az egyes életkorok tekintetében olyan mértékủ összefüggést kapjunk, ami ugyancsak megfelel a valódi, tapasztalati értékeknek. Az 5.táblázatban feltüntettük azokat a korrelációkat, amelyek a HINDLEY és OWEN (1978) által közölt életkorok között fennállnak. A 2. és az 5. táblázat összehasonlítása alapján látjuk, hogy a képességek stabilitását kifejező korrelációk tekintetében is lehet viszonylag jó egyezést mutató adatbázist készíteni.

Természetesen egyetlen egyenlet által meghatározott rendszer determinisztikus összefüggéseit nem könnyủ véletlen számok néhány további egyenletben megadott hozzákeverésével úgy „elrontani”, hogy azok aztán minden tekintetben megfeleljenek a mért adatoknak. Ezért a lehetséges alternatívákon belül arra törekedtünk, hogy az egymástól távolabbi életkorokra kapjunk minél reálisabb adatokat. 
5. táblázat. A longitudinális felmérésnek megfelelő szimulált adatok közötti korrelációk

\begin{tabular}{|r|c|c|c|c|}
\hline Kor & 5 éves & 8 éves & 11 éves & 14 éves \\
\hline 8 éves & 0,987 & \multicolumn{3}{|l}{} \\
\hline 11 éves & 0,852 & 0,913 & & \\
\hline 14 éves & 0,642 & 0,701 & 0,888 & \\
\hline 17 éves & 0,619 & 0,656 & 0,796 & 0,960 \\
\hline
\end{tabular}

Az itt bemutatott megoldásban az 5 és a 17 évesek adatai közötti összefüggés megegyezik HINDLEY és OWEN adatával, a szimulált adatok közötti többi korreláció a valóságban tapasztaltnál némileg nagyobb.

A szimulált adatbázis számára a fejlődési folyamatokat az ötödiktől a huszonnegyedik éves korig számítottuk ki. Érdemes egy pillantást vetni ezekre a fejlődési folyamatokra, illetve az azokat ábrázoló görbékre. Az előzőekben már bemutattuk, hogy ezek az adatok realisztikusak, nagyon jól megközelítik a tapasztalati adatokat. A jelenség szemléltetésére, a tanulók közötti sokféle különbség illusztrálására kiválasztottunk az adatbázisból tíz ilyen fejlődési folyamatot, ezeket a 2.ábrán mutatjuk be.

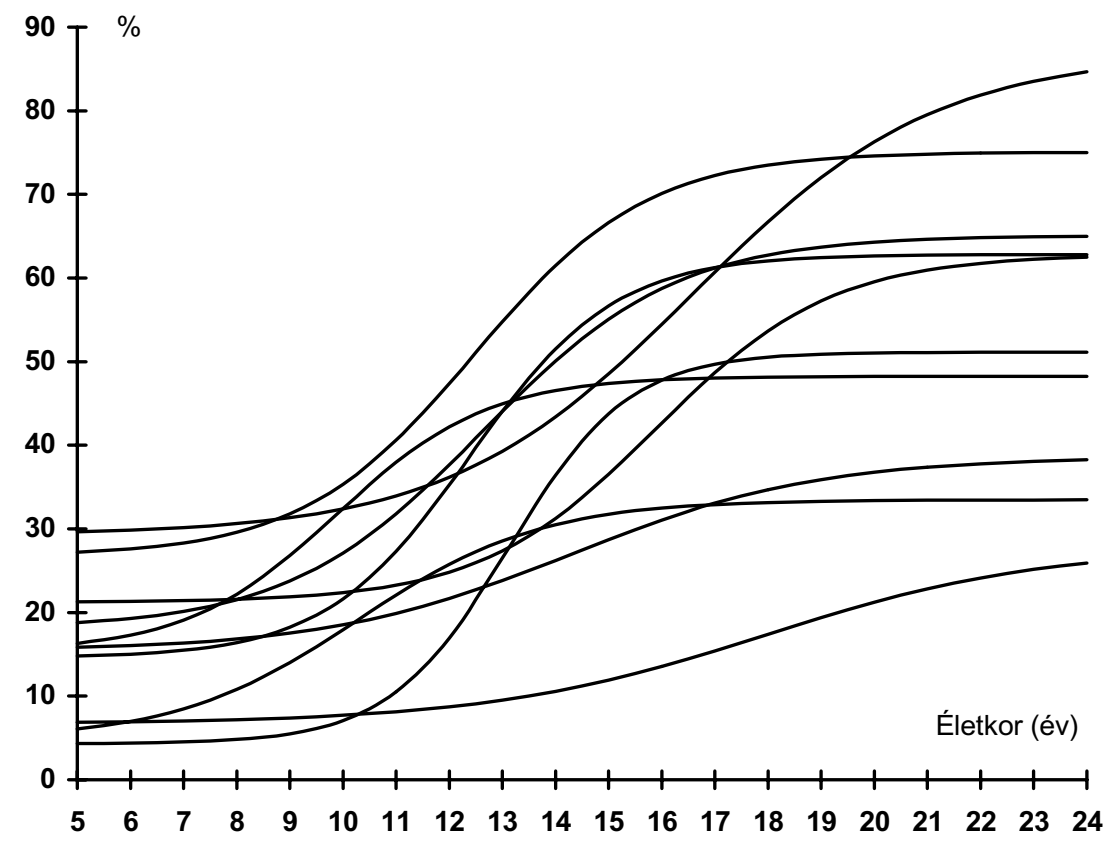

2. ábra. A szimulált adatbázisból kiválasztott tíz fejlődésgörbe 
Amint az az ábrán látható, a fejlődési vonalak valóban többször átmetszik egymást. Jól megfigyelhető, hogy a különböző korai szakaszok fejlettségi szintjei nem felelnek meg annak, amit később elérnek a görbéknek megfeleltethető tanulók. A fejlettségi sorrend többször is megváltozik, a korábban egymáshoz közel álló görbék között később nagy különbségek lesznek.

A fejlődés változatos összképet mutat, hétköznapi gondolkodásunk számára legalábbis szokatlan, hogy a tanulók ilyen változatos fejlődési pályákat futhatnak be. Érdemes ezért ellenőrizni, mennyire realisztikus ez a leírás, milyen mértékben van összhangban ez a kép a tapasztalattal, a valódi felmérésekből származó adatokkal. Ezért kiszámítottuk ennek a tíz adatsornak a korábban már elemzett életkorok közötti összefüggéseit (6. táblázat). A korrelációk jó egyezést mutatnak mind a mért adatokkal (lásd a 2. táblázatot), mind pedig a teljes szimulált adatbázisra számított összefüggésekkel (lásd az 5. táblázatot).

6. táblázat. A tíz kiválasztott görbe egyes pontjai közötti korrelációk

\begin{tabular}{|c|c|c|c|c|}
\hline Kor & 5 éves & 8 éves & 11 éves & 14 éves \\
\hline 8 éves & 0,975 & \multicolumn{2}{|l}{} \\
\hline 11 éves & 0,780 & 0,890 & & \\
\hline 14 éves & 0,580 & 0,652 & 0,835 & 0,947 \\
\hline 17 éves & 0,682 & 0,693 & 0,750 & 0 \\
\hline
\end{tabular}

Az ábra jól illusztrál több, az iskolai tapasztalatból ismert jelenséget is. Például a valóságban is gyakran megfigyelhető, hogy 11-12 éves korban néhány gyerek „elhúz" a többiektől, de később a társaik utolérik, esetleg meg is előzik őket. Az ábrán megfigyelhető a fejlődés polarizációjaként ismert jelenség is: a tanulók között fiatalabb korban még kisebb különbségek fokozatosan növekednek. Míg egyes tanulók fejlődése szinte stagnál, mások látványosan változnak.

\section{A SZIMULÁCIÓ EREDMÉNYEINEK ÉRTÉKELÉSE: KORLÁTOK ÉS LEHETŐSÉGEK}

A bemutatott adatbázis sok tekintetben hasonlít egy olyan adathalmazra, amit akkor kapnánk, ha longitudinális felméréseket végeznénk. A valódi helyzettel azonban nem minden tekintetben egyezik meg, nem vettünk ugyanis tekintetbe a valóságban fennálló minden lényeges körülményt.

A szimuláció lényegében egy olyan helyzetnek felel meg, amelyben minden tanulóhoz hozzárendeltük a fejlödési paramétereit. Ezek az adatok egyértelműen meghatározzák a fejlődési folyamatot. Nem tesszük fel itt azt a kérdést, hogy mi a meghatározottság forrása. Az öröklött és környezeti tényezők egyaránt szerepet játszhatnak. Az állandó, azonos fejlesztő hatású környezet - ami azonban minden 
tanuló esetében más és más - ugyanúgy hozzájárulhat a fejlődés paramétereinek kialakításához, mint az öröklött tényezők.

Van több olyan ismert jelenség is, amire már korábban is utaltunk, de aminek a hatását nem vettük figyelembe a szimuláció során. Ilyen például a korai fejlettségi szint alapján kialakított vélemények stabilizáló hatása. A kialakult pozitív vagy negatív énkép, továbbá a tágabb környezet - tanárok, szülők, társak - elvárásai egyaránt a predikció, a ,jóslat” beteljesülésének valószínűségét növelik. Ha ez így van, akkor a tanulók „természetes” fejlődési pályái kissé mások lennének, amit aztán az iskola és a környezet módosít. Elméletileg nem lenne nehéz ezeket a hatásokat figyelembe venni az egyenletekben, de szinte semmit nem tudunk azok mértékéről.

Nem vettük továbbá figyelembe azt sem, hogy a tanulók környezete, annak hatásrendszere többnyire nem állandó a fejlődés egész pályája során. A gyerekek új helyre költözhetnek, új iskolába kerülhetnek, változnak a tanáraik, esetleg változhatnak a családi körülményeik is. Ezek a tényezők ugyancsak megváltoztathatják a fejlődés menetét. Nem lenne akadálya annak, hogy az ilyen hatások figyelembevételére némi „zajt” keverjünk a tiszta fejlődési folyamatokba. Nem tudjuk azonban, mekkora az a zavaró hatás, ami a fejlődést eredeti pályájáról eltéríti.

Az előző dilemmák elsősorban a modell magyarázó erejét érintik, azt, hogy mennyire járul hozzá a jelenség megértéséhez. Nem befolyásolják azonban ezek a kérdések azt, hogy a modell jól írja-e le az éppen felmért fejlődési folyamatokat és összefüggéseket.

Az említett okok miatt a szimuláció elsősorban arra alkalmas, hogy segítségével megvizsgáljuk, mi történik, ha a fejlődés bizonyos feltételek között megy végbe. Mint sok más területen, esetünkben is a „mi lenne, ha ...” jellegű kérdésekre lehet a szimuláció segítségével választ adni. Különböző lehetőségeket lehet kipróbálni, modellezni, anélkül, hogy a gyerekeket bizonytalan kimenetelü kísérleteknek tennénk ki. Következtetni lehet arra, mi lenne, ha a gyerekek más módon áramolnának az iskolarendszerben. Esetleg meg lehet vizsgálni, milyen rejtett hatások játszanak szerepet egy-egy jelenségben, amelyeket nem tudunk megragadni, mert a valóságban a maguk tiszta formájában nem jelennek meg.

\section{AZ ISKOLAI SZELEKCIÓ MODELLEZÉSE}

Az előzőekben bemutatott elemzések már szemléltették az értelmi képességek fejlődésének előrejelzésével kapcsolatos problémákat. Ilyen jellegü előrejelzés azonban mégis gyakran előfordul, hiszen lényegében minden iskolai felvételi vizsgának az a funkciója, hogy kiválassza azokat a tanulókat, akiktől leginkább elvárható, hogy a rájuk váró tanulmányi feladatokat teljesíteni tudják. Az iskolai felvételi vizsgák, illetve a szelekció általában csoportokba sorolást jelent. Bár a csoportba sorolás, a kategorizálás is egyéni döntéseken alapszik, a szelekcióval kissé más a helyzet, mint amit az egyénekkel kapcsolatban általában elmondtunk. Egy-egy csoport kiválasztása ugyanis lényegében egy-egy teljesítménysáv meghatározását jelenti, és a csoportba sorolás „helyességét” nem befolyásolja, ha a sávon belül a tanulók egymással helyet cserélnek. Rossz viszont a csoportba soroló döntés azon 
tanulók esetében, akiknek a későbbi fejlődése nem igazolja a kiválasztás alapjául szolgáló elvárásokat, azaz később már nem abba a sávba tartoznak, amelyikbe a szelekció időpontjában voltak.

Amíg az egyéni fejlődéssel és az előrejelzéssel kapcsolatban csak általános megállapításokat fogalmazhatunk meg, addig a csoportok szelekciójával kapcsolatban pontos kérdéseket tehetünk fel, és a szimuláció segítségével létrehozott adatbázis alapján számszerủ válaszokat adhatunk ezekre a kérdésekre. Adatbázisunk lényegében egy olyan „könyv”, amelyben több mint kétezer tanuló fejlődésmenete le van írva az ötödik életévtől a huszonnegyedikig. Ha tehát egy adott életkorban elkülönítünk egy csoportot, a legfejlettebb tíz-húsz százalékot, megnézhetjük, „mi lesz velük” később, milyen szintet érnek el idősebb korukban. Az így elvégezhető elemzésekben benne van az a feltevés, hogy az elkülönítés nem befolyásolja a fejlődésmeneteket. Ez a valóságban nem így van, hiszen - mint azt az előzőekben felidézett vizsgálatok eredményei tükrözik - a különböző oktatási feltételek megváltoztatják a fejlődési pályákat. A valóságban tehát még a precízen összegyüjtött longitudinális adatok sem adnának választ arra a kérdésre, mennyire volt megalapozott a szelekció, hiszen akik például nem kerültek be egy jobb fejlődési feltételeket kínáló középiskolába, azoknak esélyük sincs annak megmutatására, hogyan fejlődtek volna a másokkal azonos feltételek között.

Kiindulásként feltehetjük például azt a kérdést, hogy egy nagyobb csoportot, mondjuk a tanulók legjobban teljesítő egytizedét kiválasztva mennyi annak az esélye, hogy a tanulók többsége hosszabb idő után is ebbe a teljesítménykategóriába tartozik. A gyakorlatban ez a kérdés úgy merül fel, hogy bizonyos életkorban kiválasztjuk és elkülönítjük a tanulók legjobban teljesítő csoportját (valahány százalékát), és más feltételek között oktatjuk őket, mint a többieket. Érdemes azonban megfontolnunk, hogy mennyire bizonyul döntésünk megalapozottnak, azaz néhány év elteltével a tanulók hány százaléka fog ugyanabba a teljesítménykategóriába tartozni. Nyilvánvaló, hogy a döntés helyessége nagymértékben függ attól, hogy milyen széles teljesítménysávokat határozunk meg (a tanulók hány százaléka kerül a kiválasztott csoportba), és melyik életkorban történik a szelekció. A következőkben erre vonatkozóan végzünk néhány becslést.

Az elemzésekhez feltételezett alaphelyzet az lehet, hogy 18 éves korában a tanulók egy része belép a felsőoktatásba. Bizonyos életkorban azokat, akik intellektuális fejlettségüket tekintve társaik előtt járnak, olyan iskolákba küldjük, ahol a felsőfokú továbbtanulásra a legjobban felkészülhetnek. Kérdés az, melyik életkorban, milyen pontosan tehetjük ezt meg.

Elöször azt nézzük meg, mi történik, ha a népesség felső 10 százalékát bizonyos életkorokban kiválasztjuk. A kiválasztás feltételezésünk szerint történhet a 4., a 6 ., a 8. és a 10. évfolyamokon. Hol helyezkednének el az így kiválasztottak később? A számítások adatait a 7. táblázatban foglaltuk össze.

A táblázat azt mutatja, hogy ha például a 4. évfolyamon kiválasztjuk az akkor legfejlettebb $10 \%$-ot, ebből a csoportból a 6 . évfolyamon már csak 7,1\%, a 12. évfolyamon pedig csak a 3,9\% százalék fog az akkori felső 10\%-ba tartozni. A kiválasztott csoport százalékában ez pont tízszeres számokat jelent, azaz a 4. évfolyamon kiválasztottaknak 39\%-a marad meg a 12 évfolyamon is ebben a csoportban. 
7. táblázat. Egy korábbi időpontban kiválasztott tanulók csoportban maradásának aránya

\begin{tabular}{|c|c|c|c|c|c|}
\hline Kiválasztva & 4. évf. & 6. évf. & 8. évf. & 10. évf. & 12. évf. \\
\hline 4. évfolyamon & 10,0 & 7,1 & 4,7 & 3,9 & 3,9 \\
\hline 6. évfolyamon & & 10,0 & 7,2 & 5,5 & 5,2 \\
\hline 8. évfolyamon & & & 10,0 & 7,9 & 7,1 \\
\hline \multicolumn{1}{|r}{ 10. évfolyamon } & & & & 10,0 & 8,9 \\
\hline
\end{tabular}

Hasonlóképpen, a 6 . évfolyamon való kiválasztás 52\%-os, a 8. évfolyamon való kiválasztás $71 \%$-os, míg a 10. évfolyamon való kiválasztás $89 \%$-os biztonsággal jelzi elöre a 12. évfolyamon nyújtott teljesítményeket.

A 10\%-ot itt csak az egyszerủ áttekinthetőség és összehasonlíthatóság érdekében választottuk. Az arányok befolyásolják a tévedés esélyét, ugyanis nehezebb egy szűk, néhány százalékos csoportot megbízhatóan elkülöníteni, mint egy szélesebb sávot, a tanulók jelentős arányát magában foglaló mezőnyt kiválasztani.

Érdemes ezért a számításokat olyan adatokkal is elvégezni, amelyek közel állnak a magyar iskolarendszer valódi adataihoz. Természetesen a pontos számoknak itt nincs jelentősége, mivel egyrészt az iskolai arányok is évről évre változnak, másrészt pedig a számítások pontossága is korlátozott. Mindenesetre a következőkben a valóságnak megfelelő adatokkal dolgozunk. A számításokat elvégeztük a HALÁSZ és LANNERT (2000) által szerkesztett kötetben található, a különböző iskolatípusokra vonatkozó adatokkal is (415-419).

A következő kerekített értékeket használtuk. Egy középiskolás korú évfolyamot 114 ezer főnek tekintettünk. Feltételezzük, hogy a nyolcosztályos gimnáziumot a 4. évfolyam után 4 ezer tanuló választja (az adott életkorú népesség 3,5\%-a). A 6 . évfolyam után kb. 7000 tanuló lép be a hatosztályos gimnáziumba (a megfelelő korosztály 6,14\%-a, a már nyolcosztályos gimnáziumba bekerültekkel együtt 9,64\%). A gimnáziumba a nyolcadik elvégzése után összesen mintegy 36 ezer tanuló jár (beleértve a már korábban felvetteket is), ez az adott korosztály 31,6\%-a.

Nézzük most meg, mi történik, ha a negyedik évfolyamon kiválasztjuk a tanulók 3,5\%-át! Az adatokat a 8. táblázat tartalmazza. Látható, hogy ez a döntés a népesség $0,7 \%$-a esetében, a kiválasztottak kb. 20\%-ánál jelezte előre a megfelelő teljesítménysávot. Tehát azok közül, akiket a negyedik osztályban kiválasztottunk a nyolcosztályos tanulmányokra, nagyjából csak minden ötödik tartozik abba a felső teljesítménycsoportba, amelyben a kiválasztásakor volt.

A táblázatban azt is feltüntettük, hogyan változik az eredetileg kiválasztottaknak a felső csoportba tartozási aránya. Látható, hogy a lemorzsolódás az első két évben a legnagyobb, a hatodik évfolyamra a kiválasztottaknak már csak mintegy hatvan százaléka marad az adott teljesítménysávban. A következő két évben újabb negyven százalék kiesik, viszont így már lényegében meg is történt a lemorzsolódás, nyolcadik után már nagyjából állandó marad a felső csoportban maradók aránya. 
8. táblázat. A negyedik évfolyamon kiválasztott tanulók csoportban maradásának aránya

\begin{tabular}{|c|c|c|c|c|c|}
\hline \multirow{2}{*}{ Kiválasztva } & \multicolumn{5}{|c|}{$\begin{array}{c}\text { A későbbi években a felső 3,5\%-ban maradók aránya } \\
\text { (a kiválasztottak \%-ában) }\end{array}$} \\
\cline { 2 - 6 } & 4. évf. & 6. évf. & 8. évf. & 10 . évf. & 12. évf. \\
\hline 4. évfolyamon & 3,5 & 2,1 & 0,7 & 0,6 & 0,7 \\
a felső 3,5\% & $(100,0)$ & $(61,4)$ & $(21,4)$ & $(17,1)$ & $(20,0)$ \\
\hline
\end{tabular}

Itt érdemes felhívni a figyelmet arra, hogy nem mindegy, mely életkorban történik a kiválasztás, a jelentős megugrást eredményező, a logisztikus görbe meredeken felfutó szakaszának megfelelő életkor előtt, a gyorsuló szakaszban vagy az után. Ettől ugyanis nagymértékben függ a kiválasztás „,sikeressége”. A szimulációs számítás szempontjából viszont azt kell megjegyeznünk, hogy ezért nem mindegy, milyen képességfejlődési adatokat használunk a modellezéshez. Ezért fontos az, hogy a valóságnak megfelelő fejlődési pályákkal számoljunk, olyan képesség adataival, amelynek a fejlődése valóban jól reprezentálja az iskolázás szempontjából lényeges intellektuális fejlettséget. Sok érv szól amellett, hogy az induktív gondolkodás alkalmas erre (lásd erről bővebben CSAPÓ, 1994, 1997), és az elemzésünk annyiban realisztikus, amennyiben ez a feltételezés fennáll.

Hasonló elemzést végezhetünk a hatodik osztályban kiválasztott tanulókkal. Ha reális adatokat akarunk kapni, itt érdemes a négy és a hat évfolyamos tanulókat együtt kezelni, azaz egy olyan modellből kiindulni, mintha a negyedik után kiválasztott $3,5 \%$ és a hatodik után kiválasztott $6,14 \%$, azaz együttesen $9,64 \%$ mind a hatodik után lépne be a hatosztályos rendszerbe. Ennek a csoportnak a megfelelő sávban maradási arányait a 9. táblázatban mutatjuk be.

9. táblázat. A hatodik évfolyamon kiválasztott tanulók csoportban maradásának aránya

\begin{tabular}{|c|c|c|c|c|}
\hline \multirow{2}{*}{ Kiválasztva } & \multicolumn{4}{|c|}{ A későbbi években a felső 9,64\%-ban maradók aránya } \\
& \multicolumn{4}{|c|}{ (a kiválasztottak \%-ában) } \\
\cline { 2 - 5 } & 6. évf. & 8. évf. & 10 . évf. & 12. évf. \\
\hline $\begin{array}{c}\text { 6. évfolyamon } \\
\text { a felső 9,64\% }\end{array}$ & 9,64 & 6,8 & 5,3 & 5,0 \\
$(100,0)$ & $(71,0)$ & $(54,9)$ & $(52,3)$ \\
\hline
\end{tabular}

A 9. táblázatból látható, hogy az így - később és szélesebbre - kijelölt sávban már sokkal több tanuló marad bent. Az eredetileg, tehát a hatodik évfolyamon kiválasztottak kicsit több mint fele, pontosan 52,3\%-a ebben a csoportban jut el a középiskola végéig. 
10. táblázat. A nyolcadik évfolyamon kiválasztott tanulók csoportban maradásának aránya

\begin{tabular}{|c|c|c|c|}
\hline \multirow{2}{*}{ Kiválasztva } & \multicolumn{3}{|c|}{ A későbbi években a felső 31,6\%-ban maradók aránya } \\
& (a kiválasztottak \%-ában) \\
\cline { 2 - 4 } & 8. évf. & 10. évf. & 12. évf. \\
\hline 8. évfolyamon & 31,6 & 28,1 & 26,1 \\
a felső 31,6\% & $(100,0)$ & $(89,1)$ & $(82,5)$ \\
\hline
\end{tabular}

A nyolcadik évfolyamon történő kiválasztás hatását a 10. táblázat alapján tanulmányozhatjuk. Itt már valóban jelentősebb arányt, a népesség 31,6 százalékát választjuk ki, és a fejlődés további alakulása szempontjából csak négy évet vehetünk figyelembe.

A nyolcadik osztályban való szelekció a legmegbízhatóbb, az így kiválasztott tanulóknak már a 82,5\%-a benne marad ebben a sávban. Figyelemre méltó azonban, hogy még így is mintegy 17\% azoknak a tanulóknak az aránya, akiknél a 14 éves korban történő kiválasztás sem jelent megfelelő előrejelzést.

Az előző elemzésékből összefoglalóan kiderül, hogy minél későbbi időpontra kerül a tanulók kiválasztása, különböző jellegű iskolatípusokba sorolása, annál megbízhatóbb a kiválasztás a végső fejlettség előrejelzése tekintetében. Ez lényegében közismert pedagógiai tapasztalat, és azokban az országokban, ahol az iskolarendszer korán eltérő feltételek között működő iskolatípusokba irányítja a tanulókat, különböző reformmozgalmak tűzték zászlajukra az iskolák egységesítését. (Például Németországban Gesamtschule, Angliában a comprehensive school megteremtésére törekedve.) Az itt bemutatott módszerekkel azonban olyan elemzéseket lehet végezni, amelyek meghaladják a hétköznapi tapasztalatok megbízhatóságát, pontosságát. A szimuláción alapuló számítások a valóságos helyzethez közeli adatokat szolgáltatnak a szelekció hatásával kapcsolatban, és lehetővé teszik az egyes alternatívák összehasonlítását. Az iskolai szelekció és a gyerekek eltérő iskolákban való taníttatása természetesen nem csupán tudományos kérdés. A konkrét döntéseket az egyéni ambíciók és a különböző társadalmi folyamatok befolyásolják.

Az előző elemzésék csak egyetlen szempontra szorítkoztak, a kognitív képességek fejlődésének sajátosságaiból indultak ki, és azt vizsgálták, mi lenne, ha az iskolában a tanulók értelmi fejlődésének szabályszerűségei tisztán érvényesülnének. Azonban - ahogy korábban már jeleztük - az iskolai előmenetelt sok más faktor is befolyásolja, a kognitív fejlődést egyéb tényezők hatása árnyalja. Érdemes tehát a modelleket továbbfejleszteni. Egyrészt a felhasznált matematikai összefüggéseket további kutatási eredmények figyelembevételével lehet pontosítani. Másrészt be lehet vonni a modellekbe a különböző affektív tényezők szerepét, például a motiváció, az énkép vagy az egyéni törekvések, ambíciók alakulását. 


\title{
IRODALOM
}

Anderson, M. (1998) Intelligencia és fejlödés. Egy kognitív elmélet. Kulturtrade Kiadó, Budapest

Carroll, J. B. (1993) Human cognitive abilities. Cambridge University Press, New York

CsAPÓ B. (1994) Az induktív gondolkodás fejlődése. Magyar Pedagógia, 94, 1-2. 53-80.

CsAPó B. (1997) Development of inductive reasoning: Cross-sectional measurements in an educational context. International Journal of Behavioral Development, 20, 4. 609-626.

CsAPó B. (1998) Az új tudás képződésének az eszköze: az induktív gondolkodás. In Csapó B. (szerk.) Az iskolai tudás. 251-280. Osiris Kiadó, Budapest

CsAPÓ B. (megjelenés alatt) A képességek fejlődése és iskolai fejlesztése. Akadémiai Kiadó, Budapest

HALÁSz G., LANNeRT J., szerk. (2000) Jelentés a magyar közoktatásról. Országos Közoktatási Intézet, Budapest

HÄRNQVIST, K. (1968) Relative changes in intelligence from 13 to 18. Scandinavian Journal of Psychology, 9, 50-82.

Hindley, C. B., Owen, C. F. (1978) The extent of individual changes in IQ for ages between 6 months and 17 years, in a British longitudinal sample. Journal of Child Psychology and Psychiatry, 19, 329-350.

Jensen, A. (1969) How much can we boast IQ and scholastic achievement? Harvard Educational Review, Winter, 1-123. Magyarul (1979) Mennyiben növelhetjük az IQ-t és az iskolai teljesítményt? In Vörös L. (szerk.) Az IQvita. Az örökléselvüek argumentációja. 5-243. Felsőoktatási Pedagógiai Kutatóközpont, Budapest

NaGy J. (1971) Az elemi számolási készségek mérése és fejlettségének országos színvonala. Tankönyvkiadó, Budapest

NAGY J. (1974) A kompenzáló beiskolázási modell. Akadémiai Kiadó, Budapest

OHLsson, S. (1988) Computer simulations as research tools. International Journal of Educational Research, 12, 1. 5-34.

Schaie, K. W., Strother, C. R. (1968) A cross-sequential study of age changes in cognitive behavior. Psychological Bulletin, 70, 671-680.

VIDÁKovich T., CsAPÓ B. (1998) A szövegesfeladat-megoldó készségek fejlődése. In Közoktatás-kutatás 1996-1997. Budapest, 247-273.

\section{AN ANALYSIS OF THE EFFECT OF SCHOOL SELECTION BY MEANS OF COMPUTER SIMULATION}

\author{
CSAPÓ, BENŐ
}

This paper presents the results of a computerized simulation that was carried out to examine how reliable the early selection of students at school is. The empirical basis of the study was a large-scale assessment into the development of inductive reasoning in four age groups (5th, 7th, 9th and 11th grades). In the first phase a logistic curve was fitted to the measurement data and the parameters of the 
curve were determined. Then, a simulated database was created that meets the following conditions: the means computed from the simulated data should equal that of the measured ones, and the correlations between the ages should equal the typical correlations known from the literature. Then, using the simulated database, the chance of remaining in the same achievement level after 2, 4, and 6 years was estimated. In the analysis realistic data were used, the figures of the current Hungarian selection practice. The results show that if the upper 3.5\% of the population is sent to the academic high-school, after eight years only one quarter of them belong to the upper 3.5\%. If at the age of 12 years $9.6 \%$ is selected then more than half of them can still be found in this category. If the selection is made at the age of 14, and the upper $31.6 \%$ is selected, then four quarters of them will be in the same upper category. Other models with different data can also be computed.

Key words: $\quad$ simulation, modeling, stability of abilities, development of abilities, inductive reasoning, school selection 